Review

\title{
STRESS RESPONSE TO SURGERY AND POSSIBLE WAYS OF ITS CORRECTION
}

\author{
Igors Ivanovs, Māris Mihelsons, and Viesturs Boka
}

Surgery Department, University of Latvia, Šarlotes iela 1a, Rīga, LV-1001, LATVIA;

dr.igors.ivanovs@gmail.com

Communicated by Vija Kluša

The stress response to surgery has two main systemic effects in an organism: neuroendocrine and haemato-immunological. Neuroendocrine effects are induced by changes in the hypothalamic-pituitary-adrenal axis and the sympathetic-adrenal-medullary axis. Haematoimmunological effects are characterised by cytokine production, acute phase reaction and lymphocyte and neutrophil proliferation. All of these responses interact closely. Prolongation of the stress response can increase morbidity and worsen postoperative outcome. Surgical stress can be affected by preoperative, perioperative and postoperative factors. In this paper, we review the main neuroendocrine and haemato-immunological changes related to stress and discuss different possible approaches to minimise the stress response to surgery.

Key words: stress response to surgery, neuroendocrine response, haemato-immunological response, ways to decrease stress.

\section{INTROUCTION}

Faster and better postoperative recovery is an important goal of modern surgery. In the early postoperative period, pain and stress are the most common problems (Wu et al., 2003; Ledowski et al., 2005; Ahonen et al., 2007; Jokela et al., 2007; Wiley W. Souba, 2007). Systemic response to injury or infection involves cell signaling, cell migration, and mediator release. Minor host insults instigate a local inflammatory response that is transient and in most cases beneficial. Major host insults may propagate reactions that can become amplified, resulting in systemic inflammation and potentially detrimental responses (Souba et al., 2007; Brunicardi, 2010). Stress response to surgery is a compensatory mechanism, but it has been argued that this response is unnecessary in current surgery. If the stress response is prolonged, it results in decreased disease resistance, increased morbidity and longer hospitalisation (Kehlet, 1997; Deborah et al., 2004; Brunicardi, 2010). The stress response to surgery includes a wide range of hormonal and metabolic changes, among which two main systemic effects - the neuroendocrine and the haemato-immunological effects can be distinguished (Desborough, 2000).

\section{THE NEUROENDOCRINE RESPONSE TO SURGERY}

The central nervous system (CNS) plays a key role in orchestrating the inflammatory response. The CNS influences multiple organs through both neurohormonal and endocrine signals (Brunicardi, 2010). The neuroendocrine response to surgery is characterised by two main pathways: the hypothalamic-pituitary-adrenal axis (HPA) and the sympathetic-adrenal-medullary (SAM) axis (Elenkov et al., 2000; Segerstrom et al., 2004; Miller et al., 2007). In the HPA axis, activation is initiated during stress at the paraventricular nucleus of the hypothalamus, which secretes releasing hormones (RHs). The hypothalamic releasing hormones control the pituitary gland. The hypothalamus also exerts direct neural control over the posterior pituitary gland (Lyons et al., 1997).

The anterior pituitary gland synthesises six main hormones: corticotropin, somatotropin, prolactin, thyrotropin, follitropin and lutropin. Corticotropin, somatotropin and prolactin secretion are increased under stress. The concentrations of the other anterior pituitary hormones are not changed markedly during surgical stress. The major role in the stress response to surgery is played by corticotropin. Corticotropin promotes cortisol production in the adrenal cortex. Cortisol secretion increases several minutes after surgery, and the cortisol concentration reaches a maximum at approximately 4-6 hours after surgery, depending on the severity of the surgical trauma (Desborough, et al., 1993; Nicolson et al., 1998). A feedback mechanism operates so that the increased concentrations of circulating cortisol inhibit the secretion of corticotropin by the pituitary gland, but this mechanism appears to be ineffective after surgery, and concentrations of both hormones remain high. Cortisol promotes protein 
breakdown and gluconeogenesis in the liver as well as inhibits the use of glucose by cells. These effects lead to an increased blood glucose concentration (Desborough, 2000).

Somatotropin has an important role in growth regulation and in the cell's metabolic processes. This hormone stimulates protein synthesis and glycogenolysis, promotes lipolysis, inhibits protein breakdown and has an anti-insulin effect. The concentration of somatotropin increases after surgery in proportion to the severity of the injury (Desborough et al., 1999). Somatotropin inhibits glucose uptake and use by cells (Grainne, et al. 2005). Prolactin secretion increases as a part of the stress response to surgery. Prolactin stimulates milk secretion from the breast and has a slight metabolic influence during the stress response (Desborough, et al., 1999).

Another pituitary hormone is thyrotropin. The thyrotropin concentration may be slightly decreased during the first two hours after surgery and then return to the preoperative level. The target organ of thyrotropin is the thyroid gland, which produces the thyroid hormones thyroxine (T4) and triiodothyronine (T3). These hormones are bound to their binding proteins, albumin, thyroxine-binding pre-albumin and thyroid-binding globulin. The free thyroid hormones in the plasma are metabolically active (Edwards, 1997). Thyroid hormones stimulate the oxygen consumption of most of the metabolically active tissues of the body. As a result, cell metabolism and heat production increase. The concentrations of the thyroid hormones may decrease slightly after surgery and return to normal in several days. These changes may appear because of the close relationship between thyroid hormones, catecholamines and cortisol. Exogenous steroids suppress T3 and T4; thus, hypercortisolaemia after surgery may also depress the thyroid hormone levels (Croizer et al., 1997; Desborough, 1999).

Follitropin and lutropin are also secreted from the anterior pituitary gland. In females, follitropin is responsible for the development of the ovarian follicles, and lutropin promotes the maturation of these follicles. In males, follitropin maintains the spermatic epithelium, and lutropin stimulates the testis cells. The follitropin and lutropin plasma concentrations show variable changes after surgical stress (Desborough et al., 1999, Tilbrook et al., 2002).

Vasopressin, or arginine vasopressin, is secreted from the posterior pituitary. Vasopressin has effects on the kidneys and increases water absorption in the collecting ducts of the nephron. These effects support the preservation of adequate body fluid volumes. Vasopressin also has an endocrine function, acting with corticoliberin to stimulate the secretion of pro-opiomelanocortin from the anterior pituitary (Grainne et al., 2005). The vasopressin concentration increases in response to surgical stress (Desborough et al., 1999).

In the SAM axis, activation involves preganglionic sympathetic nervous system neurons that descend from nuclei in the brain. The release of the neurotransmitter acetylcholine from these neurons in the adrenal medulla stimulates cells to secrete adrenaline. The post-ganglionic sympathetic nervous system fibres, however, predominantly secrete noradrenaline. Therefore, activation of the SAM mainly leads to the release of both adrenaline and noradrenaline (Elenkov et al., 2000). The above-mentioned processes lead to the well-recognised cardiovascular effects of tachycardia and hypertension. In addition, the functions of the liver, pancreas, kidney and immune system are directly modified by efferent sympathetic stimulation (Elenkov et al., 2000; Sanders and Kavelaars, 2007). Pancreatic secretion is also altered in response to surgical stress: glucagon secretion is activated and insulin secretion is diminished. The decreased insulin concentration may be caused partially by the inhibition of pancreas $\beta$-cell secretion. There is also a failure of the typical cellular response to insulin, the so-called "insulin resistance".

The plasma glucagon concentration increases transiently after surgery (Desborough, 2000; Grainne et al., 2005). Glucagon promotes hepatic glycogenolysis and gluconeogenesis and increases the glucose concentration in the blood. Other stress hormones, such as cortisol and catecholamines, also facilitate glucose production as a result of increased hepatic glycogenolysis and gluconeogenesis. These factors cause the glucose concentration in the plasma to increase as a response to stress after surgery, and they are related to the intensity of the surgical injury. For example, in cardiac surgery, blood glucose concentrations increase up to 10-12 $\mathrm{mmol} / \mathrm{l}$ and remain elevated for $24 \mathrm{~h}$ after surgery (Anonymous, 1998; Grainne et al., 2005). The overall metabolic effects of the hormonal changes are the following: increased catabolism, which mobilises substrates to provide energy sources, and a mechanism to retain salt and water, thus maintaining fluid volume and cardiovascular homeostasis (Desborough et al., 1999).

\section{THE HAEMATO-IMMUNOLOGICAL RESPONSE TO SURGERY}

The immune system has developed to respond to and neutralize pathogenic micro-organisms as well as coordinate tissue repair. Systemic inflammation is characterised by exaggerated immune responses to either a sterile or infectious process. The cause of inflammatory activation needs to be addressed to resolve the dysregulated immune state (Brunicardi, 2010). Recent years show that surgery and anaesthesia exert an immunosuppressive effect (Ogawa et al., 2000, Zura et al., 2009, Veenhof et al., 2012). Both innate and adaptive immune functions are depressed (Brand et al., 2003; Franke et al., 2006; Zura et al., 2009). It has been shown that the immune response is altered with respect to phagocyte compromise, lymphocyte transformation, cytotoxicity, antibody response and the chemotactic functions of immune cells (Buunen et al., 2004; Bengmark, 2006; Golubovska et al., 2008). The balance between pro-inflammatory and anti-inflammatory processes is important. 
Cytokines play a major role in the regulation of the immune response to surgery. Cytokines are a group of small cellsignalling proteins that are essential for both the innate and the adaptive immune responses. Cytokines are produced mostly from activated leucocytes, monocytes, fibroblasts and endothelial cells as an early response to tissue injury. However, virtually all nucleated cells are potent producers of cytokines. Cytokines act on surface receptors on many different target cells, and they change protein synthesis within cells. Cytokines mediate a broad sequence of cellular responses, including cell migration, DNA replication, and immunocyte proliferation (Brunicardi, 2010). More than 50 cytokines are known. After surgery, the main cytokines released are interleukin-1 (IL-1), interleukin-6 (IL-6), and tumour necrosis factor. IL-6 is the main cytokine responsible for inducing the systemic changes known as the acute-phase response.

The changes that occur after surgery and tissue damage are known as the acute-phase response. These changes are the following: fever, leucocytosis, production of acute-phase proteins in the liver and changes in the serum concentrations of transport proteins. The combination of leucocytosis with neutrophilosis is one of the immunological effects of inflammation. Neutrophils are normally found in the blood stream. Neutrophilosis occurs during the acute phase of inflammation, particularly as a result of bacterial infection, environmental exposure, or surgical trauma. Neutrophils are one of the first-responders among the inflammatory cells to migrate towards the site of inflammation (Nathan, 2006). They migrate through the blood vessels and interstitial tissue, following chemical signals such as interleukin-8 (IL-8) and leukotriene B4. Neutrophils are recruited to the site of injury within minutes following trauma and are the hallmark of acute inflammation (Witko-Sarsat et al., 2000; Nathan, 2006).

Another important part of the acute-phase response to surgical trauma is the production of acute-phase proteins in the liver, such as C-reactive protein (CRP), fibrinogen, $\alpha 2$-macroglobulin and others. These proteins act as inflammatory mediators (Sheeran et al., 1997). The physiological role of CRP is to bind to phosphocholine expressed on the surface of dead or dying cells to activate the classical pathway of the complement system via the C1Q (a subcomponent of $\mathrm{C} 1$ complement) complex. CRP enhances phagocytosis by macrophages. Thus, CRP participates in the clearance of necrotic and apoptotic cells. CRP also plays an important role in immunity as a defence system against infections (Pepys et al., 2003). In the acute- phase response, the levels of CRP increase rapidly within two hours of surgical trauma, reaching their peak during a period of 2-4 days afterwards. Upon the resolution of the acute-phase response, CRP declines with a relatively short half-life of 18 hours. Measuring the CRP level is a screen of postoperative inflammation. Rapid, marked increases in CRP occur with inflammation, infection, trauma and tissue necrosis. The half-life of CRP is constant, and therefore, its level is mainly determined by the rate of production and the sever- ity of trauma. Researchers have shown that the CRP concentration in the plasma is the main predictive factor of worse physical condition after surgery (Hall et al., 2002).

\section{BIDIRECTIONAL NEURO-IMMUNE COMMUNICA- TION}

The haemato-immune and neuroendocrine systems interact closely, and one system influences the other during the stress response in a bidirectional regulatory circuit (Fig. 1). This regulation has been shown to be mediated in part through hormones and cytokines. Both systems have receptors for both types of signalling molecules (Elenkov et al., 2000; Segerstrom et al., 2004; Miller et al., 2007). The two main neuroendocrine pathways are the HPA and the SAM axis. Many hormones from these endocrine pathways have also been shown to be produced by, and have activity on, lymphocytes. Examples include corticoliberin, somatotropin, prolactin, thyrotropin, vasopressin and others (Smith, 2008). The catecholamines (adrenaline and noradrenaline) can also influence immune cells, as all leukocytes express adrenergic surface receptors (Smith, 2008).

Glucocorticoids have immunosuppressive properties. Immunologic changes associated with glucocorticoids include thymic involution, depressed cell-mediated immune responses reflected by decreases in T-killer and natural killer cell function, T-lymphocyte blastogenesis, mixed lymphocyte responsiveness, graft-versus-host reactions, and delayed hypersensitivity responses. Glucocorticoids inhibit neutrophil superoxide reactivity, suppress chemotaxis, and normalise apoptosis signalling mechanisms, but maintain neutrophil phagocytic function. (Brunicardi, 2010). In addition, post-ganglionic nerve fibres directly innervate lymphoid organs, including the thymus, spleen, lymph nodes and bone marrow, and influence the production and functions of immune cells (Elenkov et al., 2000; Krüger et al., 2007).

\section{WAYS TO DECREASE THE STRESS RESPONSE TO SURGERY}

Among the many factors that can influence the stress response to surgery, we can distinguish three main groups: preoperative factors, perioperative factors, and postoperative factors.

\section{The preoperative factors}

Psychological stress, anxiety and emotions. Fear, anxiety, and psychological threat of danger in the preoperative period can significantly reduce tolerance to pain and stress (Tewes, 1999). It is known that the initiation of the stress response is governed by a person's ability to cope with a particular stimulus. Therefore, psychological stress occurs when a person's ability to "cope" with a situation is exceeded (Wetsch, 2009). The stimuli pass to the limbic system in the region of the amygdala and hippocampus and to the posterior hypothalamus. Stimulation of the latter influ- 


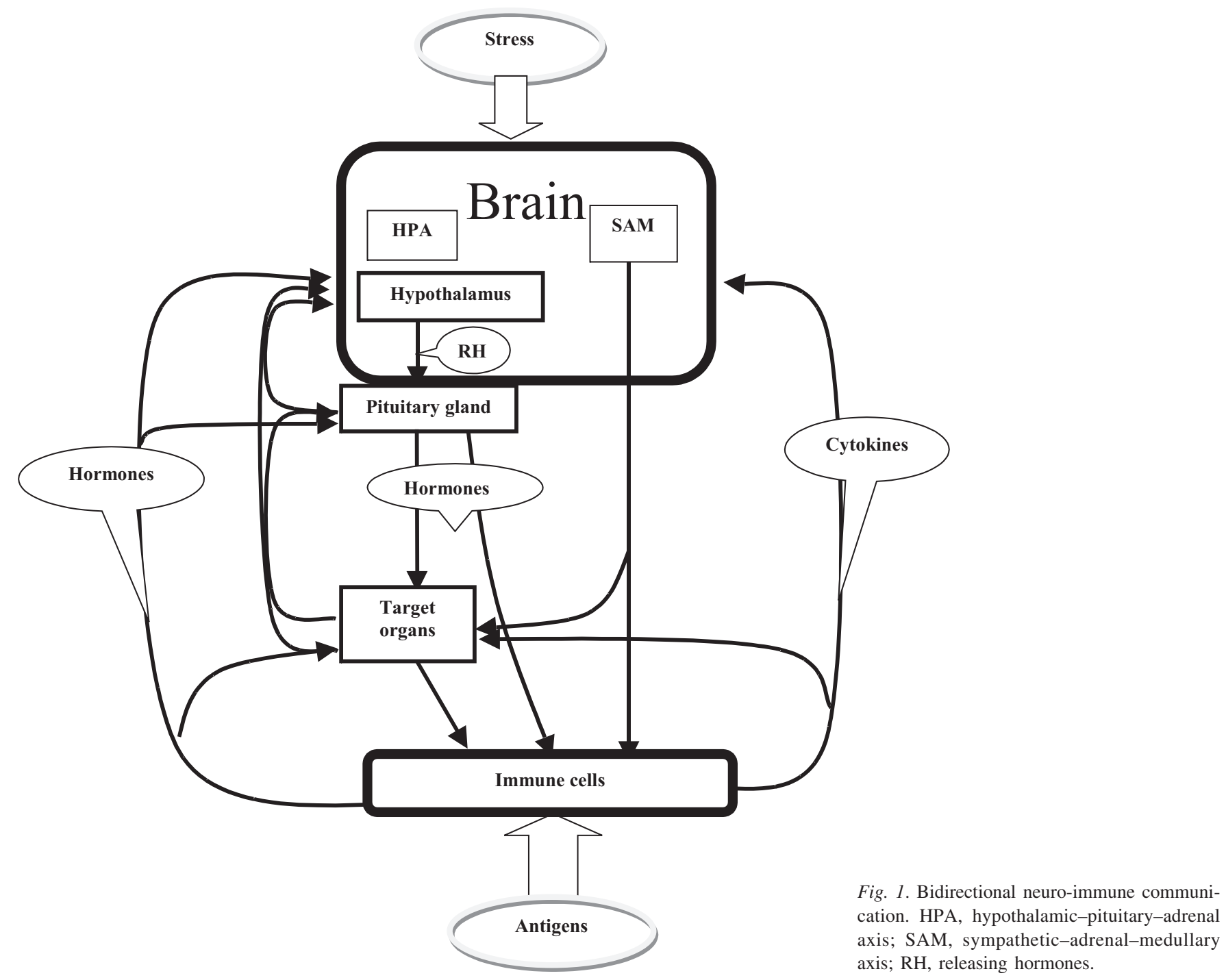

ences pituitary functions and provokes stress-related changes in an organism.

Ways to decrease the stress. To decrease anxiety in preoperative periods, we can use adequate patient management and preoperative teamwork. An important factor in decreasing preoperative stress is the preoperative educational conversation. Patients are given information about the operation, analgesia, postoperative course, prognosis, etc. (Kitching et al., 2009). Consideration should be directed to appropriate premedication therapy: anxiolytics, such as benzodiazepines, are the most popular medication for reducing fear and anxiety; additionally, painkillers such as COX-2 inhibitors can be used as a preemptive analgesia before surgery to reduce the pain and opioid requirements during the operation (Puura et al., 2006). COX-1 inhibitors are less advisable for preemptive analgesia because of antithrombotic effect and irritation of gastric mucosa, which can cause ulceration and bleeding in postoperative period. There is also an increasing interest in using $\beta$-blockers; these drugs can suppress the surgical induction of catecholamines and $\alpha_{2}$-agonists (e.g., clonidine), which can have an opioidsparing effect and reduce myocardial ischaemia (Kitching et al., 2009).
Preoperative fasting and fluid balance. Traditionally, patients for elective surgery are fasted overnight to reduce the aspiration risk; however, this practise can lead to dehydration. The reduction in the effective circulating volume is sensed by the pressure-sensitive baroreceptors in the aorta, carotid and renal arteries. Proportional to the magnitude of the volume loss, the pituitary gland is activated, and stress hormones are released (Manorama, 2003). Starvation also stimulates catabolic processes and perioperative stress.

Ways to decrease the stress. Recent guidelines have recommended a shift in fasting policy from the standard "nothing by mouth after midnight" approach to more relaxed policies that permit a period of restricted fluid intake up to two hours before surgery (Scarlett et al., 2002). Permission for clear fluid intake up to two hours preoperatively does not result in a clinically important difference in the risk of regurgitation and aspiration and can reduce perioperative stress (Grocott, 2005; Stuart, 2006). The appropriate preoperative fluid therapy with a sufficient amount of glucose is essential for maintaining the fluid balance and calorie requirement to avoid undue catabolism and decrease postoperative nausea, vomiting and pain (Maharaj, et al., 2005; Chaudhary et al., 2008). 


\section{The perioperative factors}

Anaesthesia. The specialty of anesthesia is no longer limited to the operating room. It is natural that anesthesiology, born out of the quest to relieve pain, gave rise to the field of acute and chronic pain medicine. The anesthesiologist consulting on the acute pain service may recommend oral, IM, or IV analgesia with a variety of agents, or patient-controlled analgesia (Brunicardi, 2010). Anaesthetic management depends on patient age, sex, concomitant diseases, previous medical therapy, etc. and should be tailored to each patient. General anaesthesia limits the perception of sensations during surgery but has little effect on the stress response to surgery, except for high-dose opioid anaesthesia, which may inhibit intra- but not postoperative catabolic hormonal changes (Golubovska et al., 2008). It has been suggested that even deep general anaesthesia cannot completely block the hypothalamic reaction to the noxious stimuli from an operation field.

There are differences between the two main types of general anaesthetic: inhalational and intravenous. Inhalational anaesthetics (e.g., isoflurane) have been associated with greater inflammatory response and suppression of lymphocyte functions, which can lead to greater immune suppression morbidity in the postoperative period (Karabiyik et al., 2001; Matsuoka et al., 2001). Intravenous anaesthetics have different effects on stress: ketamine may play a role in reducing postoperative pain and stress when used in addition to opioids and local anaesthetics (Tverskoy at al., 1996; Menigaux et al., 2000); in contrast, propofol promotes the inflammatory response, deepens immune suppression and supports bacterial proliferation (Bowdle et al., 2002; Golubovska et al., 2008); benzodiazepines (e.g., midazolam) suppress cortisol responses to abdominal surgery; and opioids in high doses suppress the stress response and promote surgery-induced immune suppression. However, in upper abdominal surgery, opioids are ineffective in preventing the stress response to surgery (Desborough, 2000).

Ways to decrease the stress. The use of anaesthetics with greater influence on surgical stress and a combination of intravenous and inhaled drugs is a reasonable option to decrease stress, although many intravenous and inhaled anaesthetics in normal doses have minor effects on the endocrine and metabolic functions (Lin et al., 1999; Velikovic et al., 2002; Manorama, 2003). Appropriate anaesthetic dosage is an important option for decreasing the stress response to surgery. Inadequate drug titration during anaesthesia may result in light or deep anaesthesia. During light planes of anaesthesia, feelings of pain, inadequate sleep, amnesia or muscle relaxation result in stress response. The careful titration of inhaled anaesthetic drugs and intravenous anaesthetics and the use of cardio-stable muscle relaxants are helpful to maintain adequate depth. The continuous infusion of anaesthetic drugs has proven to be excellent for preventing fluctuations in the depth of anaesthesia (Manorama, 2003).

Another way to decrease the stress response to surgery is to use local anaesthetics. The common characteristic of local anaesthetics is a reversible block of the transmission of neural impulses when placed near a nerve membrane. The neural block decreases the activation of HPA and SAM and decreases neurogenic inflammation (Coderre et al., 1993; Golubovska et al., 2008). Local anaesthetics have direct effects on endocrinal and metabolic responses. For example, extensive epidural anaesthesia with local anaesthetics can prevent the endocrine and metabolic responses to surgery in the pelvis and on the lower limbs (Desborough, 2000; Kawasaki et al., 2007). It is also assumed that local anaesthetics should decrease postoperative pulmonary complications and thromboembolic complications and improve pulmonary functions (Pöpping et al., 2008). The use of local anaesthesia improves gastrointestinal functions in the postoperative period and can decrease paralytic ileus following abdominal operations (Steinbrook, 1998). Local anaesthetics may also have systemic anti-inflammatory effects and decrease CRP and IL-6 (Hollmann et al., 2000, Bagry et al., 2008). The usage of local anaesthetics during surgery can be recommended to decrease stress-related changes.

If it is necessary to perform an operation under general anaesthesia, the combination of general anaesthetics with local anaesthetics is one of the possible options. The preemptive local anaesthesia is particularly effective when the neuronal block is performed before nociceptive stimuli are triggered. Recent studies show that this combination can decrease neuroendocrine changes related to intraoperative stress and can decrease postoperative pain (Manorama, 2003; Barczynsk et al., 2006). For example, general anaesthesia supplemented with epidural analgesia in hip replacement and abdominal surgery certainly reduces the circulatory, hyperglycaemic responses due to the inhibition of cortisol and the catecholamines (Velikovic et al., 2002).

Methods of surgical intervention. Surgery is an injury created for the purpose of treatment. The inflammatory component of the stress response depends on the extent of the injury. Procedures of short duration or abdominal laparoscopic surgeries requiring small incisions and minimal tissue handling evoke only a slight response. After laparoscopic operations, the increase in the concentrations of biochemical markers of inflammation (IL-6, CRP etc.) is not as great as after open surgery (Hollmann et al., 2000). However, the classical stress responses (cortisol, glucose, etc.) to abdominal surgery, such as cholecystectomy, are not changed greatly by reducing surgical trauma (Velickovic et al., 2002; Manorama, 2003). This observation suggests that the stimuli for the stress response arise from visceral and peritoneal afferent nerve fibres in addition to those from the abdominal wall.

Ways to decrease stress. The use of minimally invasive surgical techniques is generally associated with reduced pain and shorter hospital stays compared with open techniques. The appropriate usage of minimally invasive surgical techniques is a considerable option to decrease the inflammatory component of stress response and facilitate early discharge. 
Perioperative fluid and temperature management. Haemodynamic changes during endotracheal intubation, skin incision, and surgical manipulation provoke the secretion of stress hormones and activate HPA and SAM. Additionally, changes in the core temperature are sensed by the pre-optic area of the hypothalamus, which induces the secretion of stress hormones. Mild hypothermia $\left(35-36^{\circ} \mathrm{C}\right)$ is associated with adverse outcomes, including impaired drug metabolism, prolonged recovery from anaesthesia, cardiac morbidity, coagulopathy, wound infections, and postoperative shivering (Insler et al., 2006). The administration of cold fluids (i/v fluids, intraabdominal irrigation), large uncovered skin incisions, and internal redistribution of body heat cause body hypothermia.

Ways to decrease stress. It is essential to prevent any haemodynamic changes during surgery. The administration of $\mathrm{i} / \mathrm{v}$ fluids to avoid dehydration, maintain an effective circulating volume and prevent inadequate tissue perfusion should be considered to be a core element of perioperative management. A number of clinical studies support the notion that an approach based on administering fluids to achieve maximal left ventricular stroke volume (while avoiding excess fluid administration and consequent impairment of left ventricular performance) may improve outcomes (Grocott et al., 2005). The maintenance of constant core temperature also plays an important role in the perioperative period. Core temperature can be influenced by room temperature and body temperature. Control of body temperature can be achieved by different methods, such as perioperative warming of the patient, airflow blankets during the operation, localised heat therapy, the administration of warm fluids (i/v and intra-abdominally) and blood warmers (Scherer, 1997).

\section{Postoperative factors}

Pain management. Surgical pain is caused by inflammation from tissue trauma (surgical incision, dissection, or burns) or direct nerve injury (nerve transaction, stretching, or compression). Both factors activate HPA, SAM, and the stress response.

Ways to decrease stress. Effective postoperative analgesia is an essential factor for decreasing surgical stress. Absolute pain relief is a "gold standard" for preventing the protein breakdown and minimising endocrine and metabolic changes to the stress response (Velickovic et al., 2002). Pain relief can be achieved using different medications, including opioids (e.g., morphine), non-steroidal anti-inflammatory drugs (NSAIDs), local anaesthetics (e.g., lidocaine) and coanalgesic drugs (e.g., $\alpha_{2}$-agonists and anticonvulsants). The major goal in the management of postoperative pain is minimising the dose of medications to diminish side effects while still providing adequate analgesia. To achieve this goal, modern surgery uses a multimodal approach. The principle of the multimodal approach is to obtain good analgesic effect from different sources. This practise maximises the analgesic effect and minimises side effects, such as ileus, nausea, and sedation, especially those of opioids (Kitching et al., 2009). There is evidence that postoperative analgesia in combination with local anaesthetics is associated with a faster resolution of postoperative ileus and stimulates bowel motility. Additionally, the best option is to use different combinations of local anaesthetics, non-steroidal anti-inflammatory drugs, coanalgesics and opioids. When using such an approach, the need for opioids should be reduced (Rigg et al., 2002; Kitching et al., 2009).

Postoperative environment and nutrition. The other important factor is the environment in which a patient is situated after the operation. Behavioural and subjective changes are a part of the response to surgery. Feelings of malaise and postoperative fatigue have a strong influence on recovery from surgery and return to work (Salmon et al., 1997).

Ways to decrease stress. Postoperative fatigue and feeling of malaise is a complex multifactorial issue and can be decreased in a number of ways including early mobilisation, the avoidance of sleep disturbance, and early enteral nutrition. Such an "intensive" approach can be rewarded by early discharge from the hospital (Kehlet, 1999). The goal of nutritional support in the surgical patient is to prevent or reverse the catabolic effects of disease or injury. Factors that influence the choice of enteral formula include the extent of organ dysfunction (e.g., renal, pulmonary, hepatic, or gastrointestinal), type of operation (e.g. gastrointestinal, orthopaedic etc.), the nutrients needed to restore optimal function and healing (Brunicardi, 2010). Early enteral nutrition is an essential factor in postoperative recovery. Fears of postoperative ileus and the integrity of the newly constructed anastomosis have led to treatment typically entailing starvation with administration of intravenous fluids until the passage of flatus. However, it has since been shown that prompt postoperative enteral feeding in patients undergoing gastrointestinal resection is both effective and well tolerated even when started within 12 hours of surgery. Enteral feeding is also associated with specific clinical benefits such as reduced incidence of postoperative infectious complications and an improved wound healing response (Kitching et al., 2009). Postoperative nausea, vomiting and paralytic ileus should be avoided, and enteral or oral feeding should be used.

Bowel stimulation and enteral nutrition with a probioticsenhanced formula could be used. The term probiotic refers to "live microorganisms which when administered in adequate amounts confer a health benefit on the host" (Gorbach, 2000). The microorganisms most frequently used as probiotic agents are lactic acid bacteria (species of Lactobacillus, Enterococcus, and Bifidobacterium) and nonpathogenic antibiotic-resistant, ascosporic yeasts, especially Saccharomyces boulardii (Alvarez-Olmos et al., 2001). Probiotics have well-known effects on bowel motility, postoperative ileus, immune system and bowel microbiota (Freitas et al., 2003; Kraehenbuhl et al., 2004). The postoperative use of probiotics is another possible option to decrease the effects of stress response to surgery and decrease complications after surgery (Ivanovs et al., 2006). Probiotics stimulate the proliferation of enterocytes 
(Ishikawa et al., 1999), change the immune activity in gut-associated lymphoid tissue and decrease the proliferation of pathogenic flora in the bowel (Niers et al., 2004). Recent studies show stimulating effects of probiotics on immunoglobulin secretion (Macpherson et al., 2004). Probiotics have positive effects on leucocyte proliferation and cytokine secretion. This is especially important in postoperative stress, when both innate and adaptive immune functions are depressed and when the balance between proinflammatory and anti-inflammatory processes is impaired (Hart et al., 2004). Many studies have shown that different species of probiotic bacteria have different actions; therefore, it is better to use probiotics that contain multiple bacterial species and different probiotic bacteria to achieve the best result from probiotic therapy (Timmerman et al., 2004; Marc et al., 2005).

\section{CONCLUSION}

The stress response to surgery comprises a number of changes initiated by the neuronal activation of the hypothalamic-pituitary-adrenal axis and sympathetic-adrenalmedullary axis. The two main systemic changes are in the neuroendocrine and haemato-immune systems. Both of these systems have close interactions and influence one another. We can distinguish three main possible ways to decrease the stress response to surgery:

1. In the preoperative period, the use of adequate preoperative assessment; appropriate teamwork with a patient; educational conversation; and minimising preoperative starvation and fluid restrictions.

2. In the perioperative period, using appropriate general anaesthetics; wider use of local anaesthetics, especially in combination with general anaesthetics; minimising operative trauma; thorough intraoperative fluid management to avoid intraoperative hemodynamic changes and maintaining constant body temperature.

3 . In the postoperative period, effective postoperative analgesia using a multimodal approach, appropriate postoperative environment, early postoperative mobilisation, early enteral nutrition and probiotic use.

The appropriate use of these strategies can decrease the stress response to surgery and facilitate patient recovery.

\section{RFERENCES}

Ahonen, J., Jokela, R., Uutela, K., Huiku, M. (2007). Surgical stress index reflects surgical stress in gynaecological laparoscopic day-case surgery. Brit. J. Anaesth., 98 (4), 456-461.

Alvarez-Olmos, M., Oberhelman, R. (2001). Probiotic agents and infectious diseases: A modern perspective on a traditional therapy. Clin. Infect. Dis., 32, 1567-1576.

Anonymous (1998). Effect of intensive blood-glucose control with sulphonylureas or insulin compared with conventional treatment and risks of complications in patients with type 2 diabetes. UKPDS group. Lancet, 352, 837-853.
Bagry, H., de la Cuadra Fontaine, J. C., Asenjo, J. F., Bracco, D., Carli, F. (2008). Effect of a continuous peripheral nerve block on the inflammatory response in knee arthroplasty. Reg. Anest. Pain Med., 33 (1), 17-23.

Barczynski, M., Konturek, A., Herman, R. M. (2006). Superiority of preemptive analgesia with intraperitoneal instillation of bupivacaine before rather than after the creation of pneumoperitoneum for laparoscopic cholecystectomy: A randomized, double-blind, placebo-controlled study. Surg. Endoscopy, 20 (7), 1088-1093.

Bengmark, S. (2006). Bioecological control of inflammation and infection in critical illness. Anest. Clin. North Amer., 24, 325-337.

Benschop, R. J., Rodriguez-Feuerhahn, M. (1996). Catecholamine induced leukocytosis: Early observations, current research, and future directions. Brain Behav. Immun., 10, 77-91.

Borgdorff P. J., Ionescu, T. I., Houweling, P. L., Knape, J. T. A. (2004). Large-dose intrathecal sufentanil prevents the hormonal stress response during major abdominal surgery: A comparison with intravenous sufentanil in a prospective randomized trial. Anesth. Analg, 99 (4), 1114-1120.

Bowdle, A., Hines, R. (2002). Guest editor introduction: Pharmacology up-date 2002 seminars in anaesthesia. Perioper. Med. Pain, 11, 247-257.

Brand, J.-M., Frohn, C., Luhm, J., Kirhner, H., Schmucker, P. (2003). Early alterations in the number of circulating lymphocyte subpopulation and enchanced proinflammatory immune responce during opioid-based general anaesthesia. Shock, 20 (3), 213-217.

Brunicardi, F. C. (2010). Schwartz's Principles of Surgery. $9^{\text {th }} e d$. The McGraw-Hill Companies, Inc. USA. 1866 pp.

Buunen, M., Gholghesaei, M., Veldkamp, R., Maijer, D. W., Bonjer, H. J., Bouvy, N. D. (2004). Stress response to laparoscopic surgery: A review. Surg. Endosc., 18 (7), 1022-1028.

Chaudhary, S., Sethi, A. K., Motiani, P., Adatia, C. (2008). Pre-operative intravenous fluid therapy with crystalloids or colloids on post-operative nausea \& vomiting. Indian J. Med. Res., 127, (6), 577-581.

Chumbley, G. M., Hall, G. M. (1997). Recovery after major surgery: Does the anaesthetic make any difference? Brit. J. Anaesth., 78, 347-348.

Coderre, T. J., Katz, J., Vaccarino, A. L., Melzack, R. (1993). Contribution of central neuroplasticity to pathological pain: Review of clinical and experimental evidence. Pain, 53, 259-285.

Deborah, B., Grainne, N., George, H. (2004). Endocrine and metabolic response to surgery. Contin. Educ. Anaesth. Crit. Care Pain, 4 (5), 144-147.

Desborough, J. P. (2000). The stress response to trauma and surgery. Brit. J. Anaesth., 85 (1), 109-117.

Desborough, J. P. (1999). Physiological responses to surgery and trauma. In: Foundations of Anaesthesia (pp. 713-720). Hemmings, H. C. Jr, Hopkins, P. M. (eds.). London: Mosby.

Desborough, J. P., Hall, G. M. (1993). Endocrine response to surgery. In: Anaesthesia Review. Vol. 10 (pp. 131-148). Kaufman, L. (Ed.). Edinburgh: Churchill Livingstone.

Dimitrov, S., Lange, T., Born, J. (2010). Selective mobilization of cytotoxic leukocytes by epinephrine. J. Immunol., 184, 503-511.

Edwards, R. (1997). Thyroid and parathyroid disease. Int. Anesthesiol Clin, 35, 63-83.

Elenkov, I. J., Chrousos, G. P. (2002). Stress hormones, proinflammatory and antiinflammatory cytokines, and autoimmunity. Ann. NY Acad. Sci., 966, 290-303.

Elenkov, I. J., Wilder, R. L., Chrousos, G. P., Vizi, E. S. (2000). The sympathetic nerve-an integrative interface between two supersystems: The brain and the immune system. Pharmacol. Rev., 52 (4), 595-638.

Franke, A., Lante, W., Kurig, E., Zöller, L.G., Weinhold, C., Markewitz, A. (2006). Hyporesponsiveness of $\mathrm{T}$ cell subsets after cardiac surgery: A product of altered cell function or merely a result of absolute cell count changes in peripheral blood? Eur. J. Cardiothorac. Surg., 30 (1), 64-71. 
Freitas, M., Tavan, E., Cayuela, C., Diop, L., Sapin, C., Trugnan, G. (2003). Host-pathogens cross-talk. Indigenous bacteria and probiotics also play the game. Biol. Cell, 95, 503-506.

Golubovska, I., Vanags, I. (2008). Anaesthesia and stress response to surgery. Proc. Latv. Acad. Sci., Section B, 62 (5), 141-147.

Gorbach, S. L. (2000). Probiotics and gastrointestinal health. Amer. J. Gastroenterol., 95 (suppl), S2- S4.

Grainne, N. (2005). Hormonal and metabolic responses to trauma. Anaest. Int. Care Med., 6 (9), 313-314.

Grocott, M. P., Mythen, M. G., Gan, T. J. (2005). Perioperative fluid management and clinical outcomes in adults. Anesth. Analg., 100 (4), 1093-1106.

Hall, G. M., Salmon, P. (2002). Physiological and psychological influences on postoperative fatigue. Anesth. Analg., 95, 1446-1450.

Hart, A. L., Lammers, K., Brigidi, P., Vitali, B., Rizzello, F., Gionchetti, P., Campieri, M., Kamm. M. A., Knight, S. C., Stagg, A. J. (2004). Modulation of human dendritic cell phenotype and function by probiotic bacteria. Gut, 53, 1602-1609.

Hollmann, M. W., Durieux, M. E.,(2000). Local anaesthetics and the inflammatory response: A new therapeutic indication? Anasthesiology, 93, 858-875.

Insler, S. R., Sessler, D. I. (2006). Perioperative thermoregulation and temperature monitoring. Anesthesiol. Clin., 24 (4), 823-837.

Ichikawa, H., Kuroiwa, T., Inagaki, A., Shineha, R, Nishihira, T, Satomi, S, Sakata, T. (1999). Probiotics bacteria stimulate gut epithelial cell proliferation in rat. Dig. Dis. Sci., 44 (10), 2119-2123.

Ivanovs, I., Pavars, A., Vetra, J., Saba, M. (2006). Probiotics use in early postoperative period after large bowel resection. Colorect. Dis. 8 (4) (suppl.), 29.

Jokela, R., Ahonen, J., Valijus, M., Seppälä, T., Korttila, K. (2007). Premedication with controlled-release oxycodone does not improve management of postoperative pain after day-case gynaecological laparoscopic surgery. Brit. J. Anaesth., 98 (2), 255-260.

Karabiyik, L., Sardas, S. (2001). Comparison of genotoxicity of sevoflurane and isoflurane in human lymphocytes studied in vivo using comet assay. Mutat. Res., 492, 99-107.

Kawasaki, T., Ogata, M., Kawasaki, C., Okamoto, K., T. Sata. (2007). Effects of epidural anaesthesia on surgical stress-induced immunosuppression during upper abdominal surgery. Brit. J. Anaesth., 98 (2), 196-203.

Kehlet, H. (1997). Multimodal approach to control postoperative pathophysiology and rehabilitation. Brit. J. Anaesth., 78, 606-617.

Kehlet, H. (1999). Acute pain control and accelerated postoperative surgical recovery. Surg. Clin. N. Amer., 79, 431-443.

Kitching, A. J., O’Neill, S. S. (2009). Fast-track surgery and anaesthesia. Contin. Educ. Anaesth. Crit. Care Pain, 9 (2), 39-43.

Kraehenbuhl, J. P., Corbett, M. (2004). Immunology. Keeping the gut microflora at bay. Science, 303, 1624-1625.

Krüger, K., Mooren, F. C. (2007). T cell homing and exercise. Exerc. Imm. Rev, 13, 37-54

Latterman, R., Carli, F., Wykes, L., Schricker, T. (2003) Perioperative glucose infusion and catabolic response to surgery: The effect of epidural block. Anesth. Analg., 96, 555-562.

Ledowski, T., Bein, B., Hanss, R., Paris, A., Fudickar, W., Scholz, J., Tonner, P. H. (2005). Neuroendocrine stress response and heart rate variability: A comparison of total intravenous versus balanced anesthesia. Anesth. Analg., 101, 1700-1705.

Lin, E., Lowry, F. S., Calvano, E. S. (1999). The systemic response to injury. In: Principles of Surgery. 7th edn. (pp. 3-53). New York: McGraw Hill.

Lyons, F. M., Meeran, K. (1997). The physiology of the endocrine system. Int. Anesthesiol. Clin., 35, 1-21.
Macpherson, A. J., Uhr, T. (2004). Induction of protective IgA by intestinal dendritic cells carrying commensal bacteria. Science, 303, 1662-1665.

Maharaj, C. H., Kallam, S. R., Malik, A., Hassett, P., Grady, D., Laffey, J. G. (2005). Preoperative intravenous fluid therapy decreases postoperative nausea and pain in high risk patients. Anesth. Analg., 100 (3), 675-682.

Manorama, S. (2003). Stress response and anaesthesia altering the peri and post-operative management. Inidan J. Anaesth., 47 (6), 427-434.

Marc, G. H., Timmerman, H. M., et al. (2005). Prevention of infectious complications in surgical patients: Potential role of probiotics. Digest. Surg., 22, 234-244.

Matsuoka, H., Kurosawa, S., Horinouchi, T. (2001). Inhalation anaesthetics induce apoptosis in normal peripheral lymphocytes in vitro. Anaesthesiology, 95, 1467-1472.

Menigaux, C., Fletcher, D., Dupont, X., Guingard, B., Guirimand, F., Chauvin, M. (2000). The benefits of intraoperative small-dose ketmine on postoperative pain after anterior cruciate ligamentrepair. Anaesth. Analg., 90, 129-135.

Miller, G. E., Chen, E., Zhou, E. S. (2007). If it goes up, must it come down? Chronic stress and the hypothalamic-pituitary-adrenocortical axis in humans. Psychol. Bull., 133, 25-45.

Nathan, C. (2006). Neutrophils and immunity: Challenges and opportunities. Nat. Rev. Immunol., 6, 173-182.

Niers, L. E. M., Rijkers, G. T., Timmerman, H. M., Van Bleek, G. M., Van Uden, N. O. P., Kimpen, J. L. L.(2004). A central immunoregulatory role for IL-10 in the suppression of type 2 T-helper cell cytokines by probiotic bacteria. In: Proceedings of the XXIII European Academy of Allergology and Clinical Immunology Congress, Amsterdam. Amsteram.

Ogawa, K., Hirai, M., Katsube, T., Murayama, M., Hamaguchi, K., Shimakawa,T., Nritake, Y., Hosokawa, T., Kajiwara, T. (2000). Suppression of cellular immunity by surgical stress. Surgery, 127(3), 329-336.

Pepys, M. B., Hirschfield, G. M. (2003). C-reactive protein: A critical update. J. Clin. Invest., 111 (12),1805-1812.

Pöpping, D., Elia, N., Marret, E., Remy, C., Tramčr, M. (2008). Protective effects of epidural analgesia on pulmonary complications after abdominal and thoracic surgery: A meta-analysis. Arch. Surg., 143 (10), 990-999.

Puura, A., Puolakka, P., Rorarius, M., Salmelin, R., Lindgren, L. (2006). Etoricoxib pre-medication for post-operative pain after laparoscopic cholecystectomy. Acta Anaesthesiol Scand, 50 (6), 688-693.

Rigg, J. R., Jamrozik, K., Myles, P. S., Silbert, B. S., Peyton, P. J., Parsons, R. W., Collins, K. S. (2002). Epidural anaesthesia and analgesia and outcome of major surgery: A randomised trial. MASTER Anaesthesia Trial Study Group. Lancet, 359, 1276-1282.

Salmon, P., Hall, G. M. (1997). A theory of postoperative fatigue. J. R. Soc. Med., 90, 661-664.

Sanders, V. M., Kavelaars, A. (2007). Adrenergic regulation of immunity. In: Psychoneuroimmunology (4th edn.) (pp. 65-66). Ader, R. (Ed.). Vol. 1. Chapter 2. New York: Elsevier Academic Press.

Scarlett, M., Crawford-Sykes, A., Nelson, M. (2002). Preoperative starvation and pulmonary aspiration. New perspectives and guidelines. West Indian Med. J., 51 (4), 241-245.

Scherer, R. (1997). Intraoperative Wärmekonservierung. Viel Lärm um heiße Luft? [Intraoperative heat conservation. A lot of hot air?]. Anaesthesist, 46 (2), 81-90 (in German).

Segerstrom, S. C., Miller, G. E., (2004). Psychological stress and the human immune system: A meta-analytic study of 30 years of inquiry. Psychol. Bull., 130, 601-630.

Sheeran, P., Hall, G. M., (1997). Cytokines in anaesthesia. Brit. J. Anaesth., 78, 201-219.

Smith, E. M. (2008). Neuropeptides as signal molecules in common with leukocytes and the hypothalamic-pituitary-adrenal axis. Brain Behav. Immun., 22(1), 3-14. 
Sonohata, M., Tsunoda, K., Kugisaki, H., Someya, S., Honke, H.,Mitsunori, Kitajima, M., Mawatari, M., Hotokebuchi, T. (2009). Surgical stress differences between total hiparthroplasty and total knee arthroplasty. Int. J. Med. Sci., 1 (11), 505-509.

Steinbrook, R. A. (1998). Epidural anesthesia and gastrointestinal motility. Anesth. Analg., 86, 837-844.

Stuart, P. C. (2006). The evidence base behind modern fasting guidelines. Best Pract. Res. Clin. Anaesthesiol., 20 (3), 457-469.

Tewes, U. (1999) Concepts in psychology. In: Psychoneuroimmunology. An Interdisciplinary Introduction. Chapter 4 (pp 96-98). New York, NY: Kluwer Academic/Plenum Publishers.

Tilbrook, A.J., Turner, A.I., Clarke, I.J. (2000). Stress and reproduction: Central mechanisms and sex differences in non-rodent species. Stress, $\mathbf{5}$ (2), 83-100.

Timmerman, H. M., Koning, C. J. M., Mudler, L., Rombouts, F.M., Beynen, A.C. (2004). Monostrain, multistrain and multispecies probiotics. A comparison of functionality and efficacy. Int. J. Food Microbiol., 96, 219-233.
Veenhof, A. A., Vlug, M. S., van der Pas, M. H., Sietses, C., van der Peet, D. L., de Lange-de Klerk, E. S., Bonjer, H. J., Bemelman, W. A., Cuesta, M. A. (2012). Surgical stress response and postoperative immune function after laparoscopy or open surgery with fast track or standard perioperative care: A randomized trial. Ann. Surg., 255 (2), 216-221.

Velickovic, I., Yan, J., Gross A. J. (2002). Modifying the neuroendocrine stress response. Semin. Anaesth. Periop. Med. Pain, 21 (1), 16-25.

Souba, W. W., Fink, M. P., Jurkovich, G. J., Kaiser, L. P., Pearce, W. H., Pemberton, J. H., Soper, N. J. (2007). ACS Surgery: Principles and Practice. $6^{\text {th }} e d n$. American College of Surgeons. Philadelphia, PA: BC Decker, Inc. 1956 pp.

Witko-Sarsat, V., Rieu, P., Descamps-Latscha, B., Lesavre, P., HalbwachsMecarelli, L. (2000). Neutrophils: Molecules, functions and pathophysiological aspects. Labor. Investig., 80, 617-653.

Wu, C. L., Naqibuddin, M., Rowlingson, A. J., Lietman, S. A., Jermyn, R. M., Fleisher, L. A. (2003). The effect of pain on health-related quality of life in the immediate postoperative period. Anesth. Analg., 97, 1078-1108.

Zura, M., Sakic, K., Malenica, B., Vrbanovic, V. (2009). Immune response to surgical stress in spinal anaesthesia. Periodicum Biologorum, 111 (2), 193-196.

Received 29 February 2012

\section{PACIENTA ORGANISMA ATBILDE UZ ĶIRURĢISKO STRESU UN IESPĒJAMIE TĀS KOREKCIJAS VEIDI}

Ir zināmi divi galvenie pēcoperācijas stresa sistēmiskie efekti: neiroendokrīnais un hematoimunoloğiskais efekts. Neiroendokrīnu atbildes reakciju inducē hipotalāma-hipofīzes-adrenālās sistēmas un simpato-adrenālās-medulārās sistēmas neironu aktivizācija. Hematoimunoloğisko atbildi raksturo citokīnu produkcija, akūtas fāzes reakcija, limfocìtu un neitrofīlu leikocītu proliferācija. Visi sistēmiski efekti ir cieši saistīti un cits citu ietekmē. Pārāk izteikta stresa atbildes reakcija var novest pie palielinātas pēcoperācijas morbiditātes un pasliktināt operācijas iznākumu. Kiirurǵisku stresu var ietekmēt preoperatīvi, perioperatīvi un postoperatīvi faktori. Rakstā apkopota literatūra par izmaiṇām organismā, kuras notiek kā atbildes reakcija uz ḳirurğisku stresu un apspriestas iespējamās stratēǵijas, kā samazināt stresa atbildes reakciju un tās ietekmi uz organismu. 